\title{
Growth and Production of Determinate and Indeterminate Soybean (Glycine max L.) Influenced by Salinity Stress
}

\author{
Danang Adriansyah ${ }^{1,}{ }^{*}$, Karno $^{2}$, and Florentina Kusmiyati ${ }^{1}$ \\ ${ }^{1}$ Department of Agriculture, Diponegoro University, 50275 Semarang, Central Java, Indonesia
}

\begin{abstract}
This research was aimed to determine growth and production of two different growth types of soybean (Glycine max L.) influenced by salinity stress at various levels. This research used Factorial Design based on Completely Randomized Design 2x4 with ten replications. Two soybean growth types were used as the first factor (G1 = Determinate ; G2 = Indeterminate). The second factor was the various levels of soil salinity $\left(\mathrm{S} 0=0.42 \mathrm{dS} \cdot \mathrm{m}^{-1} ; \mathrm{S} 1=2.93 \mathrm{dS} \cdot \mathrm{m}^{-1} ; \mathrm{S} 2=4.74 \mathrm{dS} \cdot \mathrm{m}^{-1} ; \mathrm{S} 3=6.03 \mathrm{dS} \cdot \mathrm{m}^{-1}\right)$. Data were subjected to analysis of variance and tested further using Tukey's Honestly Significant Differences (HSD). Parameters observed were plant height $(\mathrm{cm})$, shoot weight $(\mathrm{g})$, shoot dry weight $(\mathrm{g})$, root length $(\mathrm{cm})$, root weight $(\mathrm{g})$, root dry weight (g), and total pod number. Results showed that indeterminate soybean is the best growth type to be planted in salinity stress based on plant height, shoot weight, shoot dry weight, root length, root weight, root dry weight, and total pod number, significantly different from determinate soybean. Salinity stress under $2.93 \mathrm{dS} \cdot \mathrm{m}^{-1}$ had the better results in plant height, root weight, and root dry weight.
\end{abstract}

\section{INTRODUCTION}

Soybean is primary crop that is developed as national supply of food nowadays. Soybean is the third highest national food needs, after paddy and maize. According to BPS (2016), in last ten years (2006-2016), soybean reached the highest peak of production in $2009(974,512$ tons) while the lowest peak of production reached in 2007 (592,534 tons). The trend of production was decreased about $3.92 \%$ in 2016.

The declining of soybean production was caused by several factors, such as crop failure as the impact of climatic change, or land conversion. Land conversion in Indonesia led to another problem. Farmers were unable to utilize sub-optimal lands. Sub-optimal lands can be founded in drylands or wetlands, which were affected by some minerals who leads to acidification or salinization. Land salinization was happened mostly in the near of the coastal or down streams of river.

The main factor of salinization is because the soil was contaminated by saltwater, causing the increase of soil salinity itself. In about 37,136 ha of lands across north coastal of Java were categorized in high until very high levels of salination (ISRI, 2015). Considerably that saline water contains high levels of cations and anions so that the product is electrically neutral, such as Natrium $\left(\mathrm{Na}^{+}\right)$or Chloride $\left(\mathrm{Cl}^{-}\right)$. Those salt were restrained in the soil, so that could affect soybean growth for long-term period.

Conventional classification that was used for saline soils are non-saline, low saline, moderate saline, strong saline, and very strong saline. Ullman (2013) was categorized them based on electrical conductivity (EC) in $\mathrm{dS} \cdot \mathrm{m}^{-1}$. They were $0-2 \mathrm{dS} \cdot \mathrm{m}^{-1}$ (non-saline), $2-4$ $\mathrm{dS} \cdot \mathrm{m}^{-1}$ (low), $4-8 \mathrm{dS} \cdot \mathrm{m}^{-1}$ (moderate), $8-16 \mathrm{dS} \cdot \mathrm{m}^{-1}$ (strong) and higher than $16 \mathrm{dS} \cdot \mathrm{m}^{-1}$ (very strong).

Susceptible crops of salinity are categorized as glycophytes. Glycophyte is used as standard of salination based on plant responsibility of salinity environments. Purwaningrahayu (2016) categorized glycophyte crops as susceptible, tolerance, and high-tolerance. Generally, soybeans were categorized as tolerance based on some researches.

The tolerance of soybean could be related to its growth types. According to Aini et al. (2012), soybean have different responses to salinity in a different varieties or genotypes. Selection of soybean varieties were obtained by their types of growth. They were classified as Determinate, Semi-Determinate, and Indeterminate.

Soybean growth response in salinity can be valued from its growth rate. The decrease in growth rate resulted from defoliation was more pronounced in plants grew under salinity stress than normal conditions ( $\mathrm{Li}$ et al., 2007). Salt damage was caused accumulation of chloride in stems and leaves, which lead to the decreasing of plant height (Bustingorri and Lavado, 2011). Increasing value of rhizosphere $\mathrm{pH}$ considered as one of the plants mechanisms to tolerate and to recover from the stress condition, which lead to better result of relative growth rate of soybean (Kuswantoro, 2014).

Salinity was inhibited the formation of new branch and facilitated the aging of old branch at various 
levels, retained the number of branches and internodes that had developed (El-Sabagh et al., 2015). The inhibitors of soybean were osmotic potential and matric potential, that were decreased due to salt stress and water shortage (Khan et al., 2016).

The period of sensitivity of indeterminate soybean to the salinity stress is prolonged compared to the determinate soybean (Nitami et al., 2013). Indeterminate soybean had ability to continue growing vegetatively during generative phase, and the increasing level of salinity stress was affected several morphological growths such as plant height, number of fully developed leaves on stem and number of primary branches (Atti et al., 2013). Plant height of soybean was significantly decreased at the end of vegetative stage (49 - 56 days) after the emergence of moderate salinity (Khan et al., 2016). Based on the research above, there was lack of researchs about plant growth types and their relations to salinity stress. This research was aimed to determine growth and production of two different growth types of soybean (Glycine max L.) influenced by salinity stress at various levels.

\section{MATERIALS AND METHODS}

This research was done in September - December 2018, located at Greenhouse B, Faculty of Animal and Agriculture, Diponegoro University. Sample analysis and other post-harvesting activity was done in Plant Physiology and Breeding Laboratory, Faculty of Animal and Agricultural Sciences, Diponegoro University, Semarang.

Two local soybean varieties (Glycine $\max \mathrm{L}$.) released from Indonesian Legumes and Tuber Crops Research Institute (ILETRI) were used in this research. They were Anjasmoro and Mallika. These samples represent each of its growth types (Determinate and Indeterminate, respectively). These samples were also chosen in a same group of mature age (medium, $80-85$ days). Anjasmoro seeds were obtained from UD Sumber Makmur, Talang Village, Rejoso District, Nganjuk Regency, East Java. Mallika seeds were obtained from KSU Mekar Mas, Jatirejo Village, Lendah District, Kulon Progo Regency, DIY Yogyakarta. Soil used in this research were Latosol and Alluvial soil. Latosol soil was used for control treatment (non-saline soil), which was obtained from Diponegoro University, Tembalang, Semarang. Alluvial soil was used for salinity treatments, which observed near the river stream or coastal area in Randugarut, Tugu, Semarang. Prepared saline soil was checked by its electrical conductivity (EC) to obtain the different salinity levels. The composure of the soil was mixed with organic fertilizer (cow manure) that used as basic fertilizer. Tools used in this research were polybag $(35 \times 35 \mathrm{~cm})$, plastic tray for sowing media, and measurement tools like EC-meter, UV-VIS spectrophotometer, microscope with camera, and ruler.

This research was used Factorial Design based on Completely Randomized Design $2 \times 4$ with ten replications. The first factor was the difference of soybean growth types, which were Determinate $\left(\mathrm{G}_{1}\right)$ and
Indeterminate $\left(\mathrm{G}_{2}\right)$. The second factor was the different levels of soil salinity, which was categorized as nonsaline soil $\left(\mathrm{S}_{0}\right)$, and three treatments of salinity soil in the range of $2 \mathrm{dS} \cdot \mathrm{m}^{-1}\left(\mathrm{~S}_{1}\right), 4 \mathrm{dS} \cdot \mathrm{m}^{-1}\left(\mathrm{~S}_{2}\right)$, and $6 \mathrm{dS} \cdot \mathrm{m}^{-1}\left(\mathrm{~S}_{3}\right)$. Data were subjected to analysis of variance and if any significances, data were tested further using Tukey's Honestly Significant Differences (HSD) at 0.05 .

This research was done by several steps, which were preparations, treatment implementation, controlling, harvesting, post-harvesting, data analysis and conclusion. Soil preparation was done by preparing soil based on each treatment in polybag. Each polybag was filled by $\pm 8 \mathrm{~kg}$ of soil. Mixed alluvial saline soil used for the salinity treatments. Composite sample was prepared thrice in each level of treatments, and the average value was used as the selected level. Default average levels of salinity in Alluvial soil that was obtained were $\pm 4-20 \mathrm{dS} \cdot \mathrm{m}^{-1}$. The excessive levels of soil salinity decreased by leached the soil to clean water to obtained lower levels selected for treatments. After the levels obtained, soil mixed with basic fertilizer, using 2 ton $\mathrm{ha}^{-1}$ cow manure, according to ISRI (2005).

Seed preparation was done by sowing two different soybean growth types (Anjasmoro and Mallika) within 14 days using plastic tray. Selected uniform seedlings were planted randomly to the experiment unit. Controlling steps were included irrigation and pest controlling. Irrigation was performed in the morning and afternoon in every day until harvesting. Pest control was done mechanically by removing pest manually using hands.

All growth and vegetative characters were measured before the crops were harvested. Harvest was performed in 85 days after planting (DAP) to obtain the physiological and production characters. Parameters that were observed were plant height $(\mathrm{cm})$, shoot weight $(\mathrm{g})$, shoot dry weight $(\mathrm{g})$, root length $(\mathrm{cm})$, root weight $(\mathrm{g})$, root dry weight $(\mathrm{g})$ and total pod number.

\section{RESULTS AND DISCUSSIONS}

\subsection{Plant Height}

Growth types and salinity levels treatments gave significant results to the observed plant height based on Tukey's HSD $(\alpha=0.05)$, but there was no interaction between the growth types and salinity levels (Table 1).

Shoot growth comparison can be viewed in Figure 1. Based on the growth types, indeterminate soybean gave better result of the observed plant height, and significantly different from determinate soybean in those two growth stages. In salinity levels, $2.93 \mathrm{dS} \cdot \mathrm{m}^{-1}$ gave the best results of the observed plant height at the end of vegetative stage than any other levels, which were significantly different from control $\left(0.42 \mathrm{dS} \cdot \mathrm{m}^{-1}\right)$. While at harvest, salinity levels of $2.93 \mathrm{dS} \cdot \mathrm{m}^{-1}$ and above was shared the same effects, but significantly different from control $\left(0.42 \mathrm{dS} \cdot \mathrm{m}^{-1}\right)$. 
Table 1. Plant height of two different kind of soybean growth types as affected by four levels of salinity stress in the end of vegetative stage and harvest

\begin{tabular}{|c|c|c|c|c|c|}
\hline \multirow{2}{*}{$\begin{array}{c}\text { Grow } \\
\text { th } \\
\text { Types }\end{array}$} & \multicolumn{4}{|c|}{ Salinity Levels $\left(\mathrm{dS} \cdot \mathrm{m}^{-1}\right)$} & \multirow{2}{*}{$\begin{array}{c}\text { Avera } \\
\text { ge }\end{array}$} \\
\hline & 0.42 & 2.93 & 4.74 & 6.03 & \\
\hline \multicolumn{6}{|c|}{----------------------------- cm --------------------------- } \\
\hline \multicolumn{6}{|c|}{ Plant Height (at the end of Vegetative Stage) } \\
\hline \multirow[t]{2}{*}{ DET } & $42.17 \pm 3$ & $72.00 \pm 2.8$ & $70.55 \pm 1.5$ & $59.44 \pm 3$ & $58.59 \pm$ \\
\hline & 90 & 9 & 4 & 56 & $3.64^{\mathrm{b}}$ \\
\hline \multirow[t]{2}{*}{ IND } & $43.67 \pm 2$ & $68.87 \pm 4.9$ & $66.28 \pm 3.8$ & $55.52 \pm 2$ & \multirow{4}{*}{$\begin{array}{r}61.04 \pm \\
4.36^{\mathrm{a}}\end{array}$} \\
\hline & 60 & 3 & $\begin{array}{r}0 \\
0.20+5.0 \\
0\end{array}$ & 64 & \\
\hline Avera & $42.92 \pm 0$ & $70.44 \pm 0.7$ & $68.42 \pm 0.9$ & $57.48 \pm 0$ & \\
\hline & $34^{\mathrm{c}}$ & $0^{\mathrm{a}}$ & $5^{\mathrm{ab}}$ & $88^{\mathrm{b}}$ & \\
\hline \multicolumn{6}{|c|}{ Plant Height (at Harvest) } \\
\hline \multirow[b]{2}{*}{ IND } & $\begin{array}{r}72.49 \pm 4 . \\
65\end{array}$ & $\begin{array}{r}106.68 \pm 7 \\
54\end{array}$ & $\begin{array}{r}98.72 \pm 2.7 \\
6\end{array}$ & $\begin{array}{r}86.97 \pm 4 \\
25\end{array}$ & \multirow{3}{*}{$\begin{array}{r}91.22 \pm \\
4.71^{\mathrm{b}} \\
101.59 \\
\pm \\
4.79^{\mathrm{a}}\end{array}$} \\
\hline & $\begin{array}{r}79.37 \pm 4 . \\
60\end{array}$ & $\begin{array}{r}110.72 \pm 5 \\
72\end{array}$ & $\begin{array}{r}111.79 \pm 5 \\
59\end{array}$ & $\begin{array}{r}104.49 \pm 4 \\
.17\end{array}$ & \\
\hline $\begin{array}{l}\text { Avera } \\
\text { ge }\end{array}$ & $\begin{array}{r}75.93 \pm 1 \\
54^{\mathrm{b}}\end{array}$ & $\begin{array}{r}108.70 \pm 0 \\
90^{\mathrm{a}}\end{array}$ & $\begin{array}{r}105.26 \pm 2 \\
92^{\mathrm{a}}\end{array}$ & $\begin{array}{r}95.73 \pm 3 . \\
92^{\mathrm{a}}\end{array}$ & \\
\hline Note: & $\begin{array}{l}\text { Different su } \\
\text { level using } \\
\text { sign of st } \\
\text { Indetermina }\end{array}$ & $\begin{array}{l}\text { rscript sho } \\
\text { key's HSD } \\
\text { dard error }\end{array}$ & $\begin{array}{l}\text { ed significa } \\
\text { Values were } \\
\text { DET = }\end{array}$ & $\begin{array}{l}\text { difference } \\
\text { ollowed by } \\
\text { terminate }\end{array}$ & $\begin{array}{l}\text { at } 0.05 \\
\text { " } \pm \text { " as a } \\
\text { IND = }\end{array}$ \\
\hline
\end{tabular}

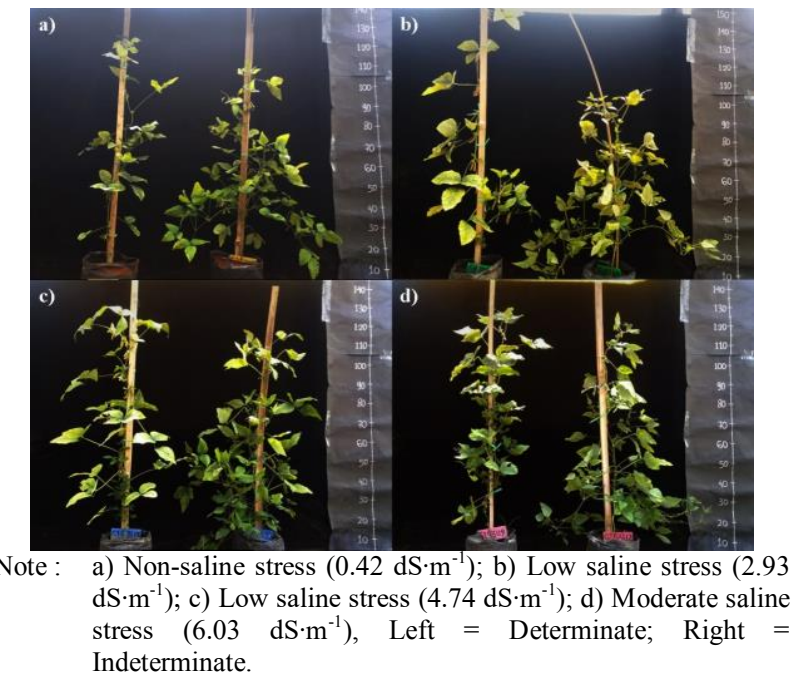

Fig. 1. Shoot growth comparison

Indeterminate soybean had better result of observed plant height than determinate soybean, because indeterminate soybean had ability to growth more constantly than determinate soybean after the end of vegetative stage until harvest. This statement was supported by Nitami et al. (2013), that the period of sensitivity of indeterminate soybean to the salinity stress was prolonged compared to the determinate soybean. Atti et al. (2013) added that indeterminate soybean had ability to continue grew vegetatively during generative phase, and the increasing level of salinity stress treatment affected several morphological growths such as plant height, number of fully developed leaves on stem and number of primary branches. Indeterminate soybean, based on El-Mohsen et al. (2013) in six different cultivars had average number of plant height in about $\pm 102 \mathrm{~cm}$.

Based on salinity levels, low saline stress (2.93 $\mathrm{dS} \cdot \mathrm{m}^{-1}$ ) gave bigger result of plant height and significantly different from control $\left(0.42 \mathrm{dS} \cdot \mathrm{m}^{-1}\right)$ and moderate saline $\left(6.03 \mathrm{dS} \cdot \mathrm{m}^{-1}\right)$, but not significantly different from low saline stress at $4.74 \mathrm{dS} \cdot \mathrm{m}^{-1}$ at the end of vegetative stage. Low saline stress $\left(2-4 \mathrm{dS} \cdot \mathrm{m}^{-1}\right)$ improved vegetative growth of both Determinate and Indeterminate soybean, which persuade them to grow faster and better in low-stress environment, and until reached moderate salinity $\left(4-6 \mathrm{dS} \cdot \mathrm{m}^{-1}\right)$, plant height was simultaneously decreased. While at harvest, there was no different responses of observed plant height between low and moderate salinity, but it was significantly different from control $\left(0.42 \mathrm{dS} \cdot \mathrm{m}^{-1}\right)$.

This phenomenon might be caused by the increasing level of salt in the soil. The more salinity levels, the more salt accumulated in soil. According to Bustingorri and Lavado (2011), salt damage from soil caused accumulation of chloride in stems and leaves, which lead to decreased plant height. Salt in low levels of saline might not affected too much to the plant height of soybean generally, until the level of salinity was increased. Khan et al. (2016) added that plant height of soybean was significantly decreased at the end of vegetative stage ( 49 - 56 days) after the emergence of moderate salinity.

\subsection{Shoot Weight and Dry Weight}

Growth types and salinity levels treatments gave significant results to the observed shoot weight and dry weight based on Tukey's HSD $(\alpha=0.05)$, but there was no interaction between the growth types and salinity levels (Table 2). Shoot weight and dry weight shared the same responses to different growth types of soybean as affected by different salinity levels.

Table 2. Shoot weight and dry weight of two different kind of soybean growth types as affected by four levels of salinity stress

\begin{tabular}{|c|c|c|c|c|c|}
\hline \multirow{2}{*}{$\begin{array}{c}\text { Growt } \\
\text { h } \\
\text { Types }\end{array}$} & \multicolumn{4}{|c|}{ Salinity Levels $\left(\mathrm{dS} \cdot \mathrm{m}^{-1}\right)$} & \multirow{2}{*}{$\begin{array}{c}\text { Avera } \\
\text { ge }\end{array}$} \\
\hline & 0.42 & 2.93 & 4.74 & 6.03 & \\
\hline \multicolumn{6}{|c|}{ 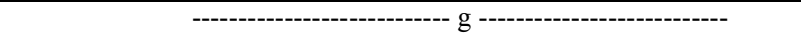 } \\
\hline \multirow{2}{*}{ DET } & $30.80 \pm 3$ & $72.05 \pm 2$ & $69.80 \pm 2$ & $70.70 \pm 3.5$ & $60.84 \pm$ \\
\hline & 09 & 72 & 75 & 4 & $6.34^{\mathrm{b}}$ \\
\hline \multirow[t]{2}{*}{ IND } & $49.05 \pm 3$ & $94.40 \pm 5$ & $99.45 \pm 6$ & $104.40 \pm 4$ & $86.83 \pm$ \\
\hline & 17 & 44 & 38 & 56 & $8.07^{\mathrm{a}}$ \\
\hline Avera & $39.93 \pm 4$ & $83.23 \pm 5$ & $84.63 \pm 6$ & $87.55 \pm 7.5$ & \\
\hline ge & $08^{\mathrm{b}}$ & $00^{\mathrm{a}}$ & $63^{\mathrm{a}}$ & $4^{\mathrm{a}}$ & \\
\hline \multicolumn{6}{|c|}{ Shoot Dry Weight } \\
\hline \multirow[t]{2}{*}{ DET } & $8.70 \pm$ & $21.65 \pm 1$ & $20.95 \pm 1$ & $19.70 \pm 1.4$ & $17.75 \pm$ \\
\hline & 1.03 & 44 & 37 & 2 & $1.92^{b}$ \\
\hline \multirow[t]{2}{*}{ IND } & $13.90 \pm 1$ & $28.10 \pm 1$ & $34.35 \pm 3$ & $31.65 \pm 2.6$ & $27.00 \pm$ \\
\hline & 18 & 58 & 18 & 8 & $2.88^{\mathrm{a}}$ \\
\hline Avera & $11.30 \pm 1$ & $24.88 \pm 1$ & $27.65 \pm 3$ & $25.68 \pm 2.6$ & \\
\hline ge & $16^{\mathrm{b}}$ & $44^{\mathrm{a}}$ & $00^{\mathrm{a}}$ & $7^{\mathrm{a}}$ & \\
\hline Note: & $\begin{array}{l}\text { Different su } \\
\text { level using } \\
\text { sign of st } \\
\text { Indeterminat }\end{array}$ & $\begin{array}{l}\text { script sho } \\
\text { ey's HSD } \\
\text { ard error }\end{array}$ & $\begin{array}{l}\text { ed signific } \\
\text { Values wer } \\
\text { DET = }\end{array}$ & $\begin{array}{l}\text { difference } \\
\text { ollowed by } \\
\text { terminate ; }\end{array}$ & $\begin{array}{l}\text { at } 0.05 \\
\text { “”” as a } \\
\text { IND = }\end{array}$ \\
\hline
\end{tabular}

Indeterminate soybean had the best value of shoot weight and dry weight and were significantly different from determinate soybean. Salinity under $2.93 \mathrm{dS} \cdot \mathrm{m}^{-1}$ had a different value significantly from control $(0.42$ 
$\left.\mathrm{dS} \cdot \mathrm{m}^{-1}\right)$ but not significant with the others $\left(4.74 \mathrm{dS} \cdot \mathrm{m}^{-1}\right.$ and $6.03 \mathrm{dS} \cdot \mathrm{m}^{-1}$ ).

Indeterminate soybean had better biomass value than determinate soybean. It also can be concluded that indeterminate soybean had ability to grew vegetatively better than determinate soybean. It was similar as Werner et al. (2016) that indeterminate soybean increased the number of plant dry matter in the initial development better than determinate soybean.

All those salinity levels $\left(2.93 \mathrm{dS} \cdot \mathrm{m}^{-1}, 4,74 \mathrm{dS} \cdot \mathrm{m}^{-1}\right.$, and $6.03 \mathrm{dS} \cdot \mathrm{m}^{-1}$ ) in the observed shoot weight and shoot dry weight were not significantly different from each other but those were significantly different from control $\left(0.42 \mathrm{dS} \cdot \mathrm{m}^{-1}\right)$. This can be concluded that low and moderate salinity affected shoot weight and dry weight similarly. Salinity stress above moderate $\left(>6.03 \mathrm{dS} \cdot \mathrm{m}^{-1}\right)$ could affected shoot weight and dry weight soybean. Aini et al. (2014) described that the total plant dry weight of most varieties of soybean at salinity under 6 $7 \mathrm{dS} \cdot \mathrm{m}^{-1}$ had decreased by $68.89 \%$. Shoot growth was more susceptible to salinity, according to the statement of Agarwal et al. (2016), shoot growth was affected more adversely than root growth.

\subsection{Root Length, Root Weight, and Root Dry Weight}

Growth types gave significant result to the observed root length, root weight and root dry weight based on Tukey's HSD $(\alpha=0.05)$. Salinity levels gave significant result to the observed root weight and root dry weight based on Tukey's HSD $(\alpha=0.05)$, but not significantly different from root length. Growth types and salinity levels gave no interaction to the observed root length, root weight and root dry weight (Table 3).

Table 3. Root growth of two different kind of soybean growth types as affected by four levels of salinity stress

\begin{tabular}{|c|c|c|c|c|c|}
\hline \multirow{2}{*}{$\begin{array}{c}\text { Growth } \\
\text { Types }\end{array}$} & \multicolumn{4}{|c|}{ Salinity Levels $\left(\mathrm{dS} \cdot \mathrm{m}^{-1}\right)$} & \multirow[t]{2}{*}{ Average } \\
\hline & 0.42 & 2.93 & 4.74 & 6.03 & \\
\hline \multicolumn{6}{|c|}{ Root Length } \\
\hline DET & $\begin{array}{r}53.04 \pm \\
1.26\end{array}$ & $\begin{array}{r}52.47 \pm \\
2.26\end{array}$ & $\begin{array}{r}51.43 \pm \\
2.26\end{array}$ & $\begin{array}{r}52.39 \pm \\
2.92\end{array}$ & $\begin{array}{r}52.33 \pm \\
0.21^{\mathrm{b}}\end{array}$ \\
\hline \multirow{2}{*}{ IND } & $63.14 \pm$ & $57.41 \pm$ & $61.78 \pm$ & $60.98 \pm$ & $60.83 \pm$ \\
\hline & 3.91 & 5.03 & 3.10 & 2.40 & $0.77^{\mathrm{a}}$ \\
\hline \multirow[t]{2}{*}{ Average } & $58.09 \pm$ & $54.94 \pm$ & $56.61 \pm$ & $56.69 \pm$ & \\
\hline & 2.26 & 1.10 & 2.31 & 1.92 & \\
\hline \multicolumn{6}{|c|}{ Root Weight } \\
\hline \multirow[t]{2}{*}{ DET } & $15.35 \pm$ & $16.45 \pm$ & $15.45 \pm$ & $12.60 \pm$ & $14.96 \pm$ \\
\hline & 1.53 & 1.26 & 1.20 & 0.90 & $\begin{array}{r}0.52^{\mathrm{b}} \\
22.94 \pm\end{array}$ \\
\hline IND & $\begin{array}{r}20.45 \pm \\
2.51\end{array}$ & $\begin{array}{r}30.65 \pm \\
3.24\end{array}$ & $\begin{array}{r}20.20 \pm \\
1.11\end{array}$ & $\begin{array}{r}20.45 \pm \\
1.72\end{array}$ & $\begin{array}{r}22.94 \pm \\
1.63^{\mathrm{a}}\end{array}$ \\
\hline \multirow{2}{*}{ Average } & $17.90 \pm$ & $23.55 \pm$ & $17.83 \pm$ & $16.53 \pm$ & \\
\hline & $1.14^{\mathrm{ab}}$ & $3.18^{\mathrm{a}}$ & $1.06^{\mathrm{ab}}$ & $1.76^{\mathrm{b}}$ & \\
\hline \multicolumn{6}{|c|}{ Root Dry Weight } \\
\hline \multirow[t]{2}{*}{ DET } & $2.20 \pm$ & $2.60 \pm$ & $2.20 \pm$ & $1.85 \pm$ & $2.21 \pm$ \\
\hline & 0.27 & 0.22 & 0.21 & 0.11 & $0.31^{\mathrm{b}}$ \\
\hline \multirow[t]{2}{*}{ IND } & $3.55 \pm$ & $5.40 \pm$ & $3.30 \pm$ & $3.00 \pm$ & $3.81 \pm$ \\
\hline & 0.59 & 0.79 & 0.21 & 0.35 & $0.34^{\mathrm{a}}$ \\
\hline \multirow{2}{*}{ Average } & $2.88 \pm$ & $4.00 \pm$ & $2.75 \pm$ & $2.43 \pm$ & \\
\hline & $0.30^{\mathrm{ab}}$ & $0.63^{\mathrm{a}}$ & $0.25^{\mathrm{ab}}$ & $0.26^{\mathrm{b}}$ & \\
\hline
\end{tabular}

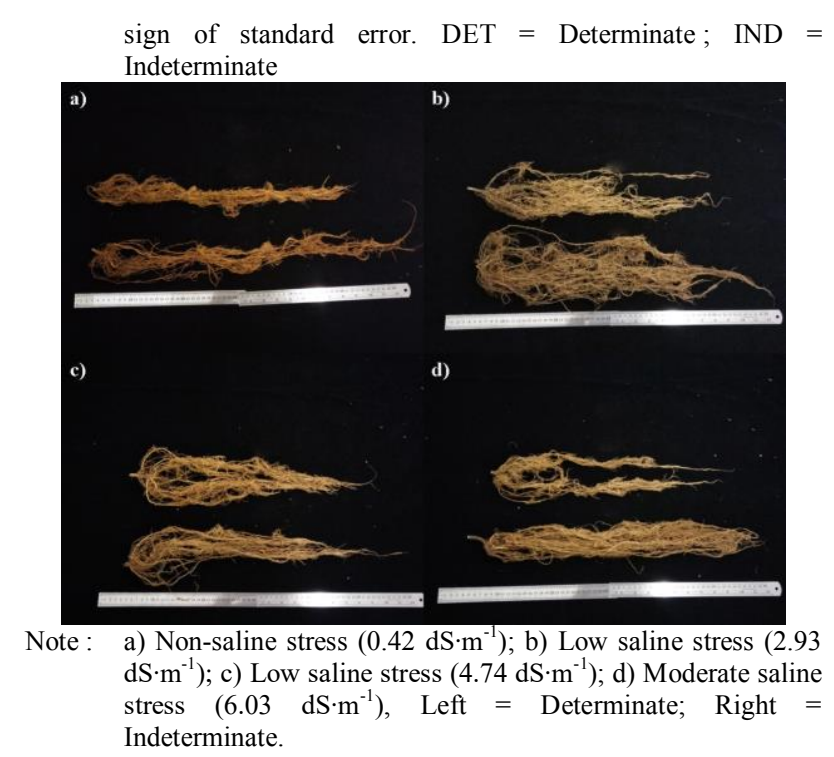

Fig. 2. Root growth comparison

Indeterminate soybean had better root growth in every aspect (root length, root weight and root dry weight) than determinate soybean. This can be concluded that indeterminate soybean's root was grow well in their rhizosphere to retain their growth under salinity stress. According to Trindade et al. (2010), indeterminate genotypes had the best results of root dry weight compared to determinate and semi-determinate genotypes, based on two different condition of harvests (pod setting and early pod filling). Indeterminate soybean also adapted well and absorbed more water under salinity stress. Júnior et al. (2017) assumed that indeterminate growth habit was consumed more water than determinate growth, and it can also be inferred that determinate growth habit are more adequate to tolerate water stress than indeterminate growth habit.

Root weight and root dry weight under low saline stress $\left(2.93 \mathrm{dS} \cdot \mathrm{m}^{-1}\right)$ had the best results and significantly different from moderate saline $\left(6.03 \mathrm{dS} \cdot \mathrm{m}^{-1}\right)$. This can be concluded that the increasing level of salinity in above $2.93 \mathrm{dS} \cdot \mathrm{m}^{-1}$ could decreased root weight and root dry weight values. This statement was supported by Agarwal et al. (2016) that soil salinity in above $6 \mathrm{dS} \cdot \mathrm{m}^{-1}$ reduced dry matter accumulation in both shoot and root weight of soybean. The factor of lower value of root growth in salinity treatments could have been caused by leaching. Leaching, as explained by Safitri et al. (2018) decreased soil salinity in terms of water that was leached by the effect of rainfall or extensive irrigation. Leaching increased water loss and developed lower size and biomass of roots.

\subsection{Total Pod Number}

Growth types gave significant results to the observed total pod number based on Tukey's HSD $(\alpha=0.05)$. Salinity levels gave significant results to the observed total pod number. There was no interaction between the growth types and salinity levels in the observed total pod number pod number (Table 4). 
Table 4. Total pod number of two different kind of soybean growth types as affected by four levels of salinity stress

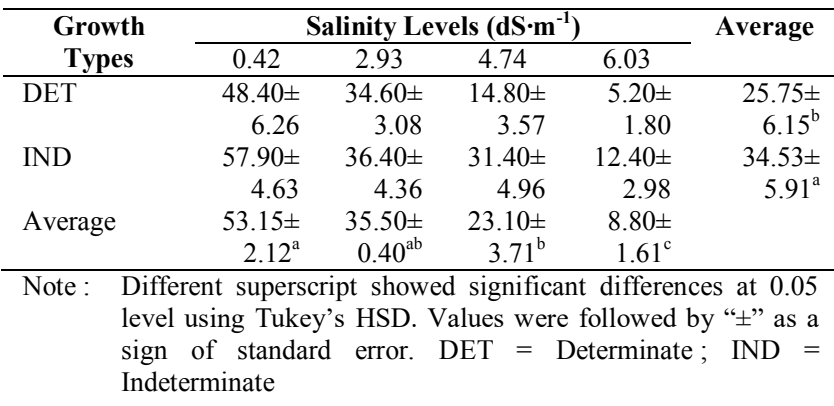

Indeterminate soybean had the best result of total pod number and significantly different from determinate soybean. Non-saline stress $\left(0.42 \mathrm{dS} \cdot \mathrm{m}^{-1}\right)$ gave the best result of total pod number and significantly different from other salinity levels $\left(4.74 \mathrm{dS} \cdot \mathrm{m}^{-1}\right.$ and $\left.6.03 \mathrm{dS} \cdot \mathrm{m}^{-1}\right)$, except for $2.93 \mathrm{dS} \cdot \mathrm{m}^{-1}$.

This can be concluded that indeterminate soybean had better result of total pod number significantly compared to determinate soybean. This result was a little lower than the research done by El-Mohsen et al. (2013) which said that indeterminate soybean in six different cultivars had an average 56,78 pods.plant ${ }^{-1}$. Indeterminate soybean had better yield, and it was explained by Khan et al. (2017) that during reproductive development of indeterminate growth types, young vegetative tissues directly competed with seeds developing for assimilate supply.

\section{CONCLUSSIONS}

Indeterminate soybean is the best growth type to be planted in salinity stress based on plant height, shoot weight, shoot dry weight, root length, root weight, root dry weight, and total pod number, and significantly different from determinate soybean. Salinity stress under $2.93 \mathrm{dS} \cdot \mathrm{m}^{-1}$ had the better results in plant height, root weight, root dry weight and significantly different from other saline treatments.

\section{REFERENCES}

1. Agarwal, N., A. Kumar, S. Agarwal, A. Singh, Int. J. Curr. Microbiol. Appl. Sci., 4(2), 123-134 (2015)

2. Aini, N., E. Mapfumo, Z. Rengel, C. Tang, Int. J. Plant Physiol. Biochem., 4(4), 52-58 (2012).

3. Aini, N., Syekhfani, W. S. D. Yamika, P. R. Dyah, A. Setiawan, Agrivita, 36(3), 201-209 (2014).

4. Atti, S., R. Bonnell, D. Smith, S. Prasher, Can. Water Resour J., 29(4), 209-222 (2013).

5. Bureau Statistics of Indonesia. (bps.go.id/linkTableDinamis/view/id/871) (2016).

6. Bustingorri, C., R. S. Lavado, Sci. Agric. (Piracicaba, Braz.), 68(1), 102-108 (2011).

7. El-Mohsen, A. A. A., G. O. Mahmoud, S. A. Safina, J. Plant Breed. Crop Sci., 5(5), 91-102 (2013).
8. El-Sabagh, A., S. Sorour, A. Ueda, H. Sancoka, C. Barutçular, AJA, 2(5), 138-141 (2015).

9. Júnior, C. S. M., C. R. da Silva, M. C. Sanches, O. T. Hamawaki, L. B. de Sousa, Pesq. Agropec. Bras., 52(6), 419-425 (2017).

10. Khan, M. S. A., M. A. Karim, M. M. Haque, M. M. Islam, A. J. M. S. Karim, M. A. K. Mian, Pertanika J. Trop. Agric. Sci., 39(2), 167 - 180 (2016).

11. Khan, H. A., K. H. M. Siddique, T. D. Colmer, J Exp Bot., 68(8), 2001-2011 (2017).

12. Kuswantoro, H., Int. J. Bio., 6(3), 11-17 (2014).

13. Li X., P. An, S. Inanaga, A. E. Eneji, K. Tanabe, J. Plant. Nutr., 29, 1499-1508 (2007).

14. Nitami, H., T. Sato, T. Matsunami, R. Itoh, T. Ikeda, Jpn. J. Crop Sci., 82(2), 141-149 (2013).

15. Purwaningrahayu, R. D., IPTEK, 11(1), 35-48 (2016).

16. Safitri, R., E. Fuskhah, Karno, J. Agro Complex, 2(3), 244-247 (2018).

17. Trindade, R. S., A. P. Araújo, M. G. Teixeira, R. Bras. Ci. Solo., 34, 115-124 (2010).

18. Werner, F., A. A. Balbinot Junior, A. S. Ferreira, M. A. Silva, H. Debiasi, J. C. Franchini, Rev. Bras. Eng. Agríc. Ambient., 20(8) : 734-738 (2016). 